\title{
VOLKMANN'S CONTRACTURE IN CHILDREN: AETIOLOGY AND PREVENTION
}

\author{
S. J. MUBARAK, N. C. CARROLL \\ From the Department of Surgery (Orthopaedic Surgery Division), \\ The Hospital for Sick Children, Toronto
}

\begin{abstract}
A review was conducted of the records of fifty-five children who were admitted to the Hospital for Sick Children in Toronto between 1955 and 1975 with a diagnosis of Volkmann's contracture in fifty-eight limbs. Ten patients had been transferred to this hospital with established ischaemia after Bryant's traction for a fractured femur; all had a very poor outcome. Thirteen other cases of Volkmann's contracture affecting the superficial posterior compartment had been treated with a fixed Thomas' splint and a Bradford frame after fractures of the femoral shaft. Supracondylar fractures of the elbow resulting in Volkmann's contracture frequently had both an arterial injury and a compartment syndrome. Most of the fifty-five children reviewed here had not had early appropriate treatment. For the past twenty-one years the frequency of Volkmann's contracture has not declined in spite of many published reports on the compartment syndrome, and the hazards of supracondylar fractures and of Bryant's traction.
\end{abstract}

In 1881 Richard von Volkmann described the paralysis and contracture resulting from the application of tight bandages to the injured extremity. He suggested that the contracture was due to interruption of the arterial blood supply. Initially, the blame was laid upon the splints used to immobilise the fractures. However, in 1909 Thomas reported on cases which developed a "Volkmann's contracture" although there had been no fracture and no splint had been used.

Murphy (1914) became one of the first to recognise that haemorrhage or oedema in muscle with its surrounding envelope of fascia could produce pressure ischaemia. Murphy suggested, and later Jepson (1926) demonstrated, that early decompression of the limb would prevent the sequelae of paralysis and contracture. Theories regarding venous obstruction (Brooks 1922) were strongly challenged by Griffiths (1940), who considered that arterial injury with reflex spasm to the collateral vessels was the primary cause of Volkmann's ischaemia. Recently, with better definition of the anatomy of the compartments and the development of devices to measure pressure, we have come to realise that Volkmann's ischaemic contracture is caused by untreated compartment syndromes which can exist without any major arterial injury.

The objectives of this review were threefold: to classify the causes of Volkmann's contracture in children; to compare the frequency in the past twenty years with the frequency in an earlier report from the Hospital for Sick Children (Thomson and Mahoney
1951); and to publicise the pitfalls of diagnosis and treatment for the better prevention of this disastrous complication.

\section{METHOD AND MATERIAL}

A review was conducted of the records of all children with a diagnosis of Volkmann's contracture hospitalised at the Hospital for Sick Children in Toronto between 1955 and 1975. Fifty-five children between the ages of two and sixteen years had developed a Volkmann's contracture in fifty-eight limbs. The records were carefully reviewed to document errors that had led to the eventual Volkmann's contracture. All injuries were classified into one of the two types described by Holden (1975): Type I, which might involve a major artery, occurred proximal to the site at which ischaemia subsequently developed (above the elbow or above the knee); or Type II where direct trauma to the limb and subsequent ischaemia occurred at the same site (below the elbow or below the knee).

In regard to the developing ischaemia important factors that were investigated included the time from injury to diagnosis and treatment, the method of treatment, and the early clinical findings (pulse, pain, increased compartmental pressure, sensory and motor deficit).

The resulting functional deficit in each limb was rated as severe, moderate or mild. Limbs with marked sensory and motor loss and contracture were rated severe. Limbs with digital hypo-aesthesia, intrinsic paralysis and contracture of the muscles of only the deep compartment were graded moderate. Limbs with only slight intrinsic contracture and intact motor and sensory function were placed in the mild group.

\section{RESULTS}

The fifty-five children (fifty-eight limbs) with Volkmann's contracture were seen in the twenty-one years of this review. This is the same incidence as in the previous

S. J. Mubarak, M.D., Assistant Professor, Division of Orthopedics and Rehabilitation, University of California. San Diego, University Hospital, 225 West Dickinson Street, San Diego, California 92103, U.S.A.

N. C. Carroll, M.D., F.R.C.S.(C)., The Hospital for Sick Children, 555 University Avenue, Toronto, Ontario, Canada M5G 1 X8.

Requests for reprints should be sent to Dr S. J. Mubarak. 


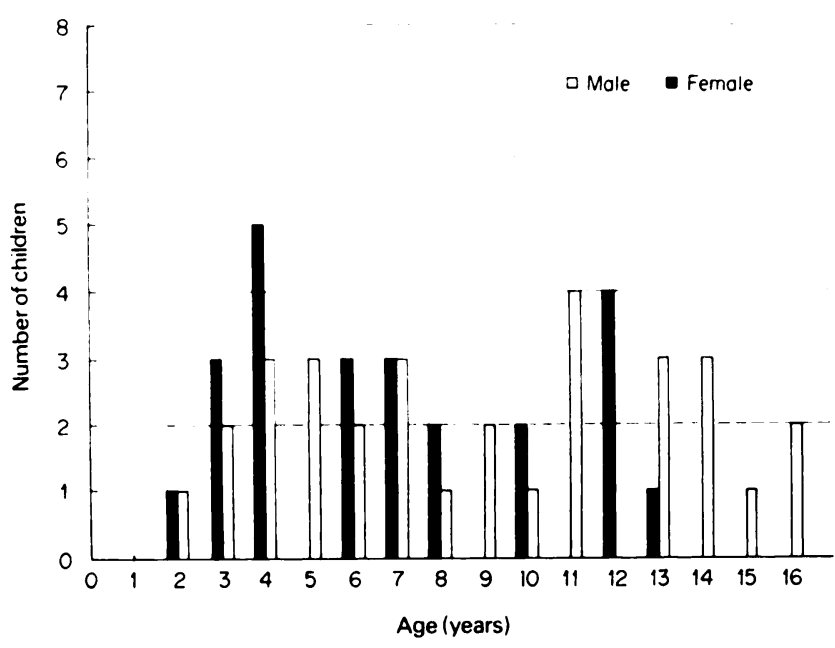

Fig. 1

Ages of fifty-five children with Volkmann's contracture.

review from this institution (Thomson and Mahoney 1951). Thirty-three of the children (60 per cent) were admitted to the Hospital for Sick Children with well-established ischaemia or contractures necessitating reconstructive operations. In these referred patients complete details of the early findings and treatment were frequently absent.

There were twenty-four girls and thirty-one boys. The mean age was eight years with a range from two to sixteen years (Fig. 1). All contractures involved either the leg and foot or forearm and hand. The leg was involved thirty-six times and the forearm twenty-two. Only twelve of the fifty-eight limbs (22 per cent) underwent fasciotomies, all of which were performed more than twenty-four hours after injury.

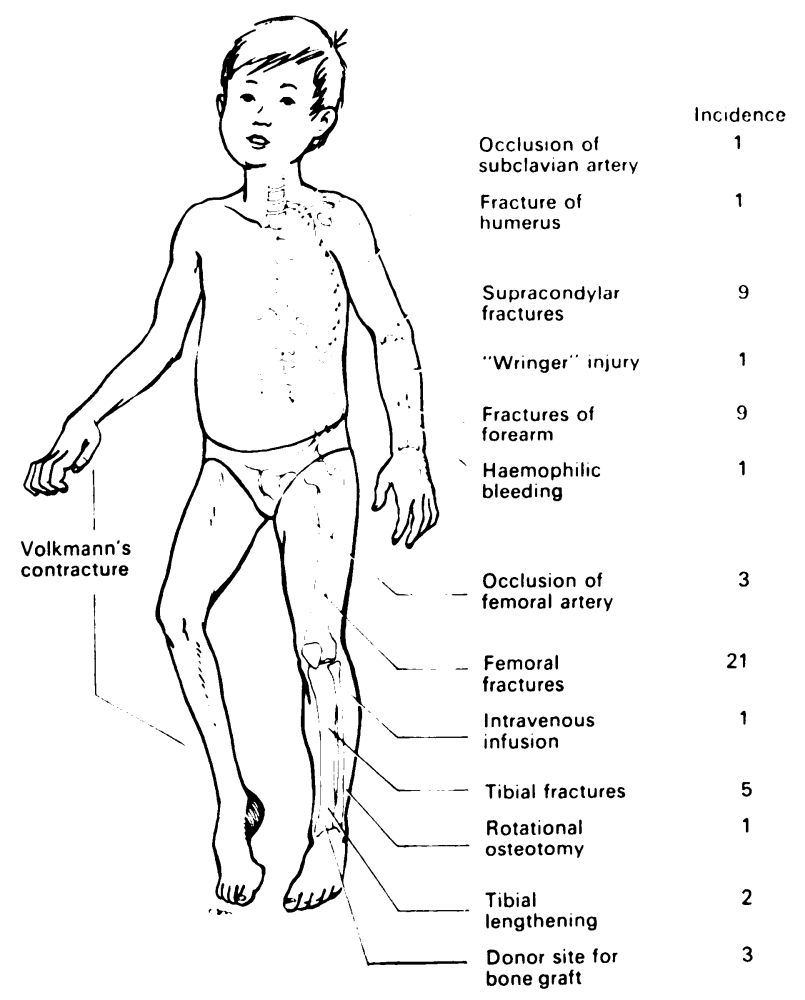

Fig. 2

Causes of Volkmann's contracture in fifty-eight limbs (fifty-five children).

Thirty-five of the injuries were classified as Type I and twenty-three as Type II. Seventy-four per cent of the Type $I$ injuries resulted in a severe contracture compared to 60 per cent of the Type II injuries.

The most common initiating cause (Fig. 2) in the

Table I. Fractures of the humerus associated with Volkmann's contracture

\begin{tabular}{|c|c|c|c|c|c|c|c|c|}
\hline Case & $\begin{array}{c}\text { Age } \\
\text { of } \\
\text { patient } \\
\text { (years) }\end{array}$ & Sex & Injury & $\begin{array}{c}\text { Compartments } \\
\text { involved }\end{array}$ & $\begin{array}{l}\text { Time from } \\
\text { injury to } \\
\text { diagnosis }\end{array}$ & $\begin{array}{c}\text { Treatment of } \\
\text { ischaemia }\end{array}$ & $\begin{array}{c}\text { Number of } \\
\text { reconstructive } \\
\text { operations }\end{array}$ & Result \\
\hline 1 & 6 & $\mathbf{M}$ & Supracondylar & Volar & $>3$ days & Cast changed & 2 & Severe \\
\hline 2 & 6 & $\mathbf{F}$ & Supracondylar & Volar & $>3$ days & None & 2 & Severe \\
\hline 3 & 7 & $\mathbf{M}$ & Supracondylar & Volar & 24 hours & $\begin{array}{l}\text { Cast removed } \\
\text { Stellate block } \\
\text { Skeletal traction }\end{array}$ & 0 & Severe \\
\hline 4 & 8 & $\mathbf{F}$ & Supracondylar & Volar & 24 hours & Cast changed & 0 & Moderate \\
\hline 5 & 3 & $\mathbf{M}$ & Supracondylar & Volar & $>3$ days & None & 1 & Mild \\
\hline 6 & 4 & $\mathbf{M}$ & Supracondylar & Volar & 6 hours & $\begin{array}{l}\text { Cast removed } \\
\text { Skeletal traction }\end{array}$ & 0 & Severe \\
\hline 7 & 8 & $F$ & Supracondylar & Volar & 48 hours & $\begin{array}{l}\text { Explored } \\
\text { Fasciotomy }\end{array}$ & 2 & Severe \\
\hline 8 & 7 & $\mathbf{M}$ & Supracondylar & Volar & 48 hours & $\begin{array}{l}\text { Stellate block } \\
\text { Fasciotomy } \\
\text { Skeletal traction }\end{array}$ & 1 & Severe \\
\hline 9 & 10 & $\mathbf{F}$ & Supracondylar & Volar & $>3$ days & None & 0 & Severe \\
\hline 10 & 4 & $\mathbf{F}$ & Shaft & Dorsal & $>3$ days & None & 1 & Severe \\
\hline
\end{tabular}


arm was a fracture of the humerus (ten cases-Type I injury), nine of these being extension-type supracondylar fractures of the distal humerus and the tenth a fracture of the shaft. The volar compartment of the forearm was the compartment of primary involvement with supracondylar fractures (Table I). Eight of the supracondylar fractures underwent primary closed reduction and were immobilised with the elbow flexed to more than 90 degrees, which resulted in weak or absent pulses in seven. When the ischaemia was recognised, the fracture was re-manipulated or skeletal traction was applied in six limbs. Exploration of the artery and fasciotomy was performed twice.
In Type II injuries of the forearm fractures of both the radius and ulna were the most common (Table II). All nine patients had involvement of the volar compartment at least. In only two cases was a fasciotomy performed (Case 12 at three days and Case 15 at five days).

In the lower limb the most common cause was fracture of the femoral shaft (Type I injury: twenty patients, twenty-one limbs). Five patients had an associated head injury which delayed recognition of the ischaemia. In nine patients treated with Bryant's traction, no diagnosis was made nor was the ischaemia recognised until the contracture had fully developed

Table II. Fractures of the forearm associated with Volkmann's contracture

\begin{tabular}{|c|c|c|c|c|c|c|c|c|}
\hline Case & $\begin{array}{c}\text { Age } \\
\text { of } \\
\text { patient } \\
\text { (years) }\end{array}$ & Sex & Injury & $\begin{array}{c}\text { Compartments } \\
\text { involved }\end{array}$ & $\begin{array}{l}\text { Time from } \\
\text { injury to } \\
\text { diagnosis }\end{array}$ & $\begin{array}{c}\text { Treatment of } \\
\text { ischaemia }\end{array}$ & $\begin{array}{l}\text { Number of } \\
\text { reconstructive } \\
\text { operations }\end{array}$ & Result \\
\hline 11 & 5 & $\mathbf{M}$ & Radius and ulna & Volar & $>3$ days & None & 5 & Severe \\
\hline 12 & 11 & $\mathbf{M}$ & Radius and ulna & Volar and dorsal & $>3$ days & Fasciotomy & 2 & Severe \\
\hline 13 & 4 & $\mathbf{F}$ & Radius and ulna & Volar & $>3$ days & None & 1 & Severe \\
\hline 14 & 8 & $\mathbf{M}$ & Radius and ulna & Volar & $>3$ days & None & 1 & Severe \\
\hline 15 & 3 & $\mathbf{F}$ & Ulna & Volar and dorsal & $>3$ days & Fasciotomy & 2 & Severe \\
\hline 16 & 13 & $\mathbf{M}$ & Radius and ulna & Volar & 48 hours & Repair of brachial artery & 3 & Severe \\
\hline 17 & 14 & $\mathbf{M}$ & $\begin{array}{l}\text { Epiphysial } \\
\text { separation of } \\
\text { distal radius }\end{array}$ & Volar & $>3$ days & None & 0 & Moderate \\
\hline 18 & 13 & $\mathbf{M}$ & Radius and ulna & Volar & 6 hours & Cast split & 0 & Mild \\
\hline 19 & 13 & $\mathbf{M}$ & Radial neck & Volar & 12 hours & Cast split & 0 & Mild \\
\hline
\end{tabular}

Table III. Fractures of the femoral shaft treated with Bryant's traction and associated with Volkmann's contracture

\begin{tabular}{|c|c|c|c|c|c|c|c|c|}
\hline Case & $\begin{array}{c}\text { Age } \\
\text { of } \\
\text { patient } \\
\text { (years) }\end{array}$ & Sex & $\underset{\text { involved }}{\text { Limb }}$ & $\begin{array}{c}\text { Compartments } \\
\text { involved }\end{array}$ & $\begin{array}{l}\text { Time from } \\
\text { injury to } \\
\text { diagnosis }\end{array}$ & $\begin{array}{c}\text { Treatment of } \\
\text { ischaemia }\end{array}$ & $\begin{array}{l}\text { Number of } \\
\text { reconstructive } \\
\text { operations }\end{array}$ & Result \\
\hline 20 & 5 & $\mathbf{F}$ & Fractured & $\begin{array}{l}\text { Ant., Lat., } \\
\text { S.P., D.P. }\end{array}$ & $>3$ days & None & 1 & Severe \\
\hline 21 & 4 & $\mathbf{M}$ & Fractured & $\begin{array}{l}\text { Ant., Lat., } \\
\text { S.P., D.P. }\end{array}$ & 36 hours & $\begin{array}{l}\text { Fasciotomy } \\
\text { Skeletal traction }\end{array}$ & 3 & Severe \\
\hline 22 & 2 & F & Fractured & S.P., D.P. & $>3$ days & None & 2 & Severe \\
\hline 23 & 4 & $\mathbf{M}$ & Fractured & $\begin{array}{l}\text { Ant., Lat., } \\
\text { S.P., D.P. }\end{array}$ & $>3$ days & None & 2 & Severe \\
\hline 24 & 6 & $\mathbf{F}$ & $\begin{array}{l}\text { Fractured } \\
\text { Uninjured }\end{array}$ & $\begin{array}{l}\text { Ant., Lat., } \\
\text { Ant., Lat. }\end{array}$ & $>3$ days & None & $\begin{array}{l}2 \\
1\end{array}$ & $\begin{array}{l}\text { Severe } \\
\text { Severe }\end{array}$ \\
\hline 25 & 6 & F & Uninjured & $\begin{array}{l}\text { Ant., S.P., } \\
\text { D.P. }\end{array}$ & $>3$ days & None & 1 & Severe \\
\hline 26 & 3 & $\mathbf{M}$ & Fractured & Ant., S.P. & $>3$ days & None & 1 & Severe \\
\hline 27 & 7 & $\mathbf{F}$ & Fractured & $\begin{array}{l}\text { Ant., Lat., } \\
\text { S.P., D.P. }\end{array}$ & 36 hours & Artery dilated & 2 & Severe \\
\hline 28 & 4 & $\mathbf{F}$ & Fractured & S.P., D.P. & $>3$ days & None & 2 & Severe \\
\hline
\end{tabular}

Ant.-Anterior Lat._Lateral S.P.-Superficial posterior D.P.-Deep posterior 
(Table III). In two patients the non-fractured leg was the site of the contracture; one of these patients also sustained a Volkmann's contracture of the fractured side. The results in all were poor. The average age of these children was four and a half years (range two and a half to seven).

Fractures of the femoral shaft in the other eleven children were treated with Buck's skin traction on a fixed Thomas' splint elevated on a Bradford frame (Table IV). The compartment primarily involved in this underwent decompression and in each case it was delayed more than twenty-four hours.

There were six miscellaneous causes of compartment syndromes with resulting Volkmann's contracture (Table VI). A boy aged fifteen with haemophilia managed his bleeding forearm at home for five days before seeking medical attention. He was treated with appropriate immediate fasciotomy on admission and was left with a mild residual deformity. There was one case of a wringer injury with subsequent Volkmann's

Table IV. Fractures of the femoral shaft treated with skin traction and Bradford frame and associated with Volkmann's contracture

\begin{tabular}{|c|c|c|c|c|c|c|c|}
\hline Case & $\begin{array}{c}\text { Age } \\
\text { of } \\
\text { patient } \\
\text { (years) }\end{array}$ & Sex & $\begin{array}{c}\text { Compartments } \\
\text { involved }\end{array}$ & $\begin{array}{l}\text { Time from } \\
\text { injury to } \\
\text { diagnosis }\end{array}$ & $\begin{array}{c}\text { Treatment of } \\
\text { ischaemia }\end{array}$ & $\begin{array}{l}\text { Number of } \\
\text { reconstructive } \\
\text { operations }\end{array}$ & Result \\
\hline 29 & 9 & $\mathbf{M}$ & $\begin{array}{l}\text { Ant., Lat., } \\
\text { S.P., D.P. }\end{array}$ & 24 hours & $\begin{array}{l}\text { Thrombectomy } \\
\text { Fasciotomy }\end{array}$ & 2 & Severe \\
\hline 30 & 11 & $\mathbf{M}$ & Ant., Lat. & $>3$ days & None & 0 & Severe \\
\hline 31 & 14 & $\mathbf{M}$ & S.P. & 48 hours & Skeletal traction & 0 & Moderate \\
\hline 32 & 11 & $\mathbf{M}$ & S.P. & $>3$ days & Skeletal traction & 0 & Mild \\
\hline 33 & 5 & $\mathbf{M}$ & Ant. & $>3$ days & Skeletal traction & 0 & Moderate \\
\hline 34 & 12 & $\mathbf{F}$ & S.P. & $>3$ days & Skeletal traction & 0 & Mild \\
\hline 35 & 12 & $\mathbf{F}$ & S.P. & $>3$ days & Skeletal traction & 0 & Mild \\
\hline 36 & 13 & F & $\begin{array}{l}\text { Ant., Lat., } \\
\text { S.P., D.P. }\end{array}$ & 48 days & $\begin{array}{l}\text { Skeletal traction } \\
\text { Fasciotomy }\end{array}$ & 1 & Severe \\
\hline 37 & 10 & $\mathbf{F}$ & $\begin{array}{l}\text { Ant., Lat., } \\
\text { S.P., D.P. }\end{array}$ & 30 hours & $\begin{array}{l}\text { Thrombectomy } \\
\text { Fasciotomy } \\
\text { Skeletal traction }\end{array}$ & 3 & Severe \\
\hline 38 & 7 & $\mathbf{M}$ & S.P. & $>3$ days & Skeletal traction & 0 & Mild \\
\hline 39 & 7 & $\mathbf{F}$ & S.P. & $>3$ days & Skeletal traction & 1 & Moderate \\
\hline
\end{tabular}

Ant.-Anterior Lat._Lateral S.P.-Superficial posterior D.P.-Deep posterior

group was the superficial posterior compartment. The early findings included increased tenseness of the calf, pain on dorsiflexion of the foot, and an erythematous skin lesion over the tight calf. In most cases, early appropriate treatment was not given. However, the best results occurred in this group: four had a mild residual deficit and another three had only a moderate contracture. The typical sequel was an equinus deformity of the ankle.

Injuries to the tibia (Table V) accounted for eleven Type II injuries. The most common cause in this group was fractures of the tibial shaft (five cases); one of these fractures became infected after the compartment syndrome, with muscle necrosis. After multiple debridements, a below-knee amputation became necessary (Case 42). The second largest group included three children in which the tibia had been used as the donor site for a bone-grafting procedure. As with the fractures of the forearm, only three of these eleven patients contracture, and an unusual case in a hospitalised child aged two who developed a compartment syndrome after intravenous infusion into his leg. There were three patients who suffered primary arterial occlusions with subsequent compartment syndromes (in two instances not recognised) and Volkmann's contractures.

\section{DISCUSSION}

Volkmann's contracture is defined as the end-result of an ischaemic injury to the muscles and nerves of the limb. Volkmann's ischaemia is the acute episode of pain aggravated by passive stretching and neurological deficit resulting from ischaemia of muscle and nerve. A compartment syndrome is defined as a symptom complex due to elevated pressure of tissue fluid in the closed osseofascial compartments of the limb, interfering with the circulation to the nerves and muscles of that compartment. It represents the primary cause of 
Table V. Tibial injuries associated with Volkmann's contracture

\begin{tabular}{|c|c|c|c|c|c|c|c|c|}
\hline Case & $\begin{array}{c}\text { Age } \\
\text { of } \\
\text { patient } \\
\text { (years) }\end{array}$ & Sex & Injury & $\begin{array}{c}\text { Compartments } \\
\text { involved }\end{array}$ & $\begin{array}{l}\text { Time from } \\
\text { injury to } \\
\text { diagnosis }\end{array}$ & $\begin{array}{c}\text { Treatment of } \\
\text { ischaemia }\end{array}$ & $\begin{array}{l}\text { Number of } \\
\text { reconstructive } \\
\text { operations }\end{array}$ & Result \\
\hline 39 & 7 & $\mathbf{F}$ & Fracture & $\begin{array}{l}\text { Ant., Lat., } \\
\text { S.P., D.P. }\end{array}$ & $>3$ days & None & 4 & Severe \\
\hline 40 & 16 & $\mathbf{M}$ & Fracture & $\begin{array}{l}\text { Ant., Lat., } \\
\text { S.P., D.P. }\end{array}$ & $>3$ days & $\begin{array}{l}\text { Artery dilated } \\
\text { Fasciotomy }\end{array}$ & 3 & Severe \\
\hline 41 & 12 & $\mathrm{~F}$ & Fracture & D.P. & $>3$ days & None & 2 & Severe \\
\hline 42 & 14 & $\mathbf{M}$ & Fracture & $\begin{array}{l}\text { Ant., Lat., } \\
\text { S.P., D.P. }\end{array}$ & $>3$ days & Fasciotomy & $\begin{array}{c}4 \\
\text { (Below-knee } \\
\text { amputation) }\end{array}$ & Severe \\
\hline 43 & 6 & $\mathbf{M}$ & Fracture & $\begin{array}{l}\text { Ant., Lat., } \\
\text { S.P., D.P. }\end{array}$ & $>3$ days & None & 1 & Severe \\
\hline 44 & 12 & $\mathrm{~F}$ & $\begin{array}{l}\text { Donor site for } \\
\text { bone graft }\end{array}$ & Ant. & $>3$ days & None & 3 & Severe \\
\hline 45 & 16 & $\mathbf{M}$ & $\begin{array}{l}\text { Donor site for } \\
\text { bone graft }\end{array}$ & $\begin{array}{l}\text { Ant., Lat., } \\
\text { S.P., D.P. }\end{array}$ & $>3$ days & None & 0 & Moderate \\
\hline 46 & 11 & $\mathbf{M}$ & $\begin{array}{l}\text { Donor site for } \\
\text { bone graft }\end{array}$ & $\begin{array}{l}\text { Ant., Lat., } \\
\text { S.P., D.P. }\end{array}$ & $>3$ days & None & 0 & Moderate \\
\hline 47 & 3 & $\mathrm{~F}$ & Rotational osteotomy & Ant. & $>3$ days & None & 1 & Moderate \\
\hline 48 & 9 & $\mathbf{M}$ & Lengthening of leg & Ant. & 24 hours & Fasciotomy & 1 & Moderate \\
\hline 49 & 10 & $\mathbf{M}$ & Lengthening of leg & Ant., Lat. & $>3$ days & None & 0 & Mild \\
\hline
\end{tabular}

Table VI. Miscellaneous causes associated with Volkmann's contracture

\begin{tabular}{|c|c|c|c|c|c|c|c|c|}
\hline Case & $\begin{array}{c}\text { Age } \\
\text { of } \\
\text { patient } \\
\text { (years) }\end{array}$ & Sex & Injury & $\begin{array}{c}\text { Compartments } \\
\text { involved }\end{array}$ & $\begin{array}{c}\text { Time from } \\
\text { injury to } \\
\text { diagnosis }\end{array}$ & $\begin{array}{l}\text { Treatment of } \\
\text { ischaemia }\end{array}$ & $\begin{array}{l}\text { Number of } \\
\text { reconstructive } \\
\text { operations }\end{array}$ & Result \\
\hline 50 & 15 & $\mathbf{M}$ & Haemophilia-bleeding forearm & Volar & 2 hours & Fasciotomy & 2 & Moderate \\
\hline 51 & 4 & $\mathbf{F}$ & "Wringer" injury-forearm & Volar and dorsal & $>3$ days & None & 6 & Severe \\
\hline 52 & 2 & $\mathbf{M}$ & Intravenous infusion-leg & $\begin{array}{l}\text { Ant. } \\
\text { S.P. } \\
\text { D.P. }\end{array}$ & $>3$ days & None & 1 & Severe \\
\hline 53 & 5 & $\mathbf{M}$ & $\begin{array}{l}\text { Cardiac operation: occlusion of } \\
\text { subclavian artery - forearm }\end{array}$ & $\begin{array}{l}\text { Volar } \\
\text { Dorsal }\end{array}$ & $>3$ days & None & 1 & Severe \\
\hline 54 & 3 & $\mathbf{F}$ & $\begin{array}{l}\text { Cardiac catherisation: occlusion } \\
\text { of femoral artery - both legs }\end{array}$ & $\begin{array}{l}\text { Ant., S.P. } \\
\text { S.P. }\end{array}$ & $>3$ days & None & $\begin{array}{l}2 \\
0\end{array}$ & $\begin{array}{l}\text { Severe } \\
\text { Severe }\end{array}$ \\
\hline 55 & 7 & $\mathbf{F}$ & $\begin{array}{l}\text { Cardiac catherisation: occlusion } \\
\text { of femoral artery - leg }\end{array}$ & S.P., D.P. & $>3$ days & None & 1 & Severe \\
\hline
\end{tabular}

Ant.-Anterior Lat._Lateral S.P.-Superficial posterior

Volkmann's ischaemia and, if untreated, leads to Volkmann's contracture. It is a disorder of the small vessels. As pressure in the tissue rises, the capillaries, venules, and arterioles are occluded but the major arteries nearly always remain patent. The intracompartmental pressure rarely exceeds 80 millimetres of mercury and is more commonly between 30 and 50 millimetres in our experience (normal range 0 to 8 millimetres of mercury) (Mubarak et al. 1978).

An injury to a major artery (Type I) may produce a
D.P.-Deep posterior

compartment syndrome by one of two mechanisms. First, a compartment syndrome may result if there is an inadequate collateral circulation or if the vessel is only partially occluded (for example, arterial spasm or intimal tear). In this situation the decreased perfusion and ischaemia of both capillaries and muscles will cause an increase in the permeability of the capillary walls. The resulting oedema will cause more ischaemia and a vicious circle will be set up. Second, with complete arterial occlusion, once the circulation is restored a 
compartment syndrome may develop from postischaemic swelling. With complete arterial occlusion secondary to massive emboli or prolonged use of a tourniquet, in which the circulation is not restored, gangrene and not a compartment syndrome will result. The total time of occlusion is important. Whitesides, Harada and Morimoto (1977) demonstrated that six hours of tourniquet-induced ischaemia in dogs produced markedly elevated intracompartmental pressures after removal of the tourniquet. Thus even with restoration of the circulation, the resulting elevated pressure may prolong the ischaemia of muscle and nerve. With eight hours of complete tourniquet ischaemia nearly all muscle fibres were necrotic even without the additional insult of a post-ischaemic compartment syndrome (Whitesides et al. 1977).

Injury to the nerve can co-exist with this arterial injury or compartment syndrome. The clinical findings of these three entities overlap, making the diagnosis frequently difficult if not impossible (Table VII). All may have an associated motor or sensory deficit and

Table VII. Typical clinical findings of compartment syndrome, arterial occlusion and neurapraxia

\begin{tabular}{|l|c|c|c|}
\hline & $\begin{array}{c}\text { Compartment } \\
\text { syndrome }\end{array}$ & $\begin{array}{c}\text { Arterial } \\
\text { occlusion }\end{array}$ & Neurapraxia \\
\hline $\begin{array}{l}\text { Pressure increased in } \\
\text { compartment }\end{array}$ & + & - & - \\
Pain with stretch & + & + & - \\
$\begin{array}{l}\text { Paraesthesia or } \\
\text { anaesthesia }\end{array}$ & + & + & + \\
Paresis or paralysis & + & + & + \\
Pulses intact & + & - & + \\
\hline
\end{tabular}

pain. Careful clinical evaluation is necessary to differentiate these entities. The arterial injury usually results in absent pulses, poor skin colour and decreased skin temperature. The compartment syndrome presents elevated intracompartmental pressure (greater than 30 millimetres of mercury) (Mubarak et al. 1978) and, nearly always, intact peripheral pulses. A nerve injury usually gives little pain, and the diagnosis is often by exclusion of the other two entities.

It is important to differentiate these three entities because therapy is radically different. Nerve injury accompanying a closed fracture is usually a neurapraxia and is best treated by observation. Arterial injuries warrant immediate operative repair, and a compartment syndrome necessitates immediate decompressive fasciotomy (Mubarak and Owen 1977; Gelberman et al. 1978).

Supracondylar fractures. Supracondylar fracture of the humerus in the child is the most infamous injury associated with a Volkmann's contracture. However, increased publicity has reduced the frequency: in the
Mayo Clinic's reviews (Lipscomb 1956; Eichler and Lipscomb 1967) supracondylar fractures as a cause of Volkmann's contracture declined from nearly 50 per cent to 35 per cent over a ten-year span. More recent large series on the treatment of supracondylar fractures note no cases of Volkmann's contracture when treated by Dunlop's traction (Dodge 1972), overhead pin traction (D'Ambrosia 1972) or percutaneous pinning (Flynn, Matthews and Benoit 1974). In these series the complication rate for nerve injuries ranged from 9 to 13 per cent and for injury to the brachial artery from 8 to 18 per cent.

As has been pointed out, there is an association between supracondylar fractures, absent pulses and Volkmann's contracture. When the concept of compartment syndromes and of early fasciotomy to prevent Volkmann's contracture became popular, it was only logical that the finding of absent pulses would emerge as being in association with compartment syndromes. This misconception has no doubt caused many a physician to delay treatment of a compartment syndrome while awaiting the disappearance of the pulse.

When evaluating a child with a supracondylar fracture, a carefully documented examination of the neurovascular status must be carried out. If neurovascular deficit does exist, it is extremely important to differentiate between a nerve injury, a brachial artery injury, a compartment syndrome or a combination of these problems. If the brachial artery is affected as evidenced by decreased radial pulse and poor skin colour, immediate reduction of the fracture should be undertaken. If flexion is needed to maintain the reduction and causes loss of the pulse, one should consider traction with less flexion or percutaneous pinning of the fracture. Although absence of the radial pulse alone is not an indication for exploration if there are no other signs of ischaemia, these children must be kept under observation. Conversely, the presence of a radial pulse does not rule out a compartment syndrome or an arterial injury with adequate collateral circulation. If reduction of the fracture gives no improvement in the circulation, then arteriography should be performed. If this shows ischaemia, exploration of the anticubital fossa and an arterial repair are indicated. Fasciotomy of the forearm is indicated when there are neurological signs of a compartment syndrome and intracompartmental pressure greater than 30 millimetres of mercury (Mubarak et al. 1978).

Forearm fractures. Although receiving little attention in the literature, these injuries accounted for 22 per cent of the Volkmann's contractures in the Mayo Clinic series (Eichler and Lipscomb 1967) and 15 per cent in this series. These Type II injuries presented with the usual findings of a compartment syndrome although one patient (Case 16) also had an associated arterial injury. Prompt diagnosis and fasciotomy should improve the results substantially. 
Femoral fractures treated with Bryant's traction (Fig. 3). There were nine children with Volkmann's contracture whose femoral fractures were treated with Bryant's overhead traction. Ten limbs developed Volkmann's contractures including two on the non-fractured side. This disastrous complication of Bryant's traction was

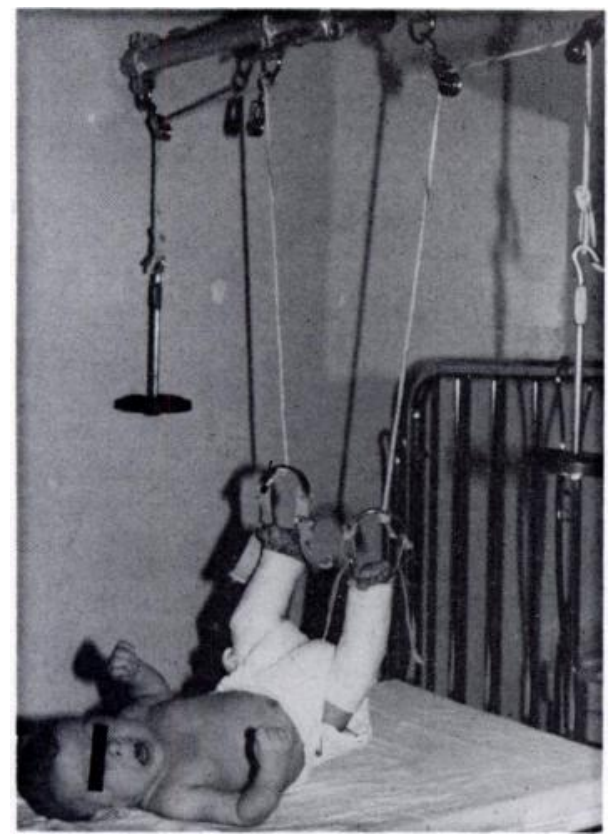

Fig. 3

Infant aged six months suspended in Bryant's traction.

first reported by Winslow in 1950 and by Thomson and Mahoney (1951). Other authors added more cases and provided insight into the probable mechanism of injury (Miller, Markin and Grossman 1952). Nicholson, Foster and Heath (1955) believed that the primary factors causing the impaired circulation were the reduction in the hydrostatic pressure in the lower limbs when held in the overhead position, aggravated by tight bandaging, shock, traction, and hyperextension of the knee. It is unproven whether in these children the contracture developed from a compartment syndrome or from the decreased perfusion alone.

It has been recommended that Bryant's traction should not be used for any child over two years of age or thirty pounds in weight (Nicholson et al. 1955). All nine children so treated in this series were older than two and a half years and had been initially treated elsewhere. They were admitted to the Hospital for Sick Children for reconstructive operations.

In placing a child in Bryant's traction, care should be taken in wrapping the leg and avoiding hyperextension of the knee; frequent neurovascular checks of the feet are mandatory. For the child over two years of age, split Russell's traction or immediate application of a spica cast is a safer alternative treatment.
Femoral fractures treated with skin traction and a Bradford frame (Fig. 4). Thomson and Mahoney in 1951 first made us aware of the association between Volkmann's contracture and femoral fractures in the older child immobilised with skin traction in a Thomas' splint elevated on a Bradford frame. They documented eight cases of Volkmann's contracture. In spite of this, an additional eleven cases have occurred in the twenty-one years of this review.

The presenting complex of symptoms in our patients has been well defined (Thomson and Mahoney 1951). The child having sustained a fracture of the femoral shaft is treated with skin traction using the Thomas' splint and Bradford frame. Twelve to fortyeight hours after injury the patient develops pain in the calf aggravated by dorsiflexion of the ankle. The skin over a tense calf is erythematous with "pressure blisters" occasionally present. Rarely, diminished pulses and decreased sensation in the distribution of the sural nerve are also noted. At this stage the physician becomes aware of the patient's difficulty and changes to a form of skeletal traction with variable success. Nearly all children in this study with this particular injury and treatment developed equinus contractures; involvement of the other three compartments of the leg was less likely. Overall results were better than most of the other groups.

Although none of the children in this study has been documented with measurement of intracompartmental pressure, it would appear that they had sustained a superficial posterior compartment syndrome. Immediate fasciotomy would have been the treatment of choice if the findings failed to relent with alterations in the

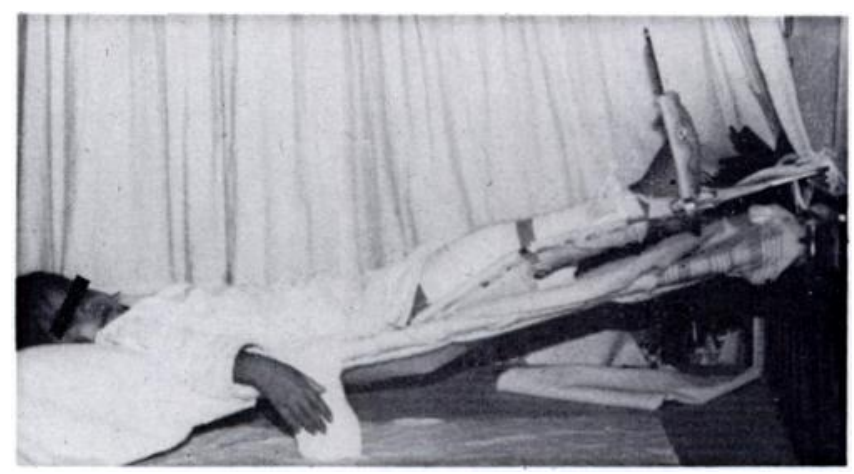

Fig. 4

A boy aged six years whose femoral fracture is immobilised with skin traction in a Thomas' splint elevated on a Bradford frame.

mode of traction. The pathogenesis of this syndrome is purely speculative but possible causes may well include: Arterial injury or spasm. With the injury (femoral fracture) occurring proximal to the later-developing contracture of the leg, one might tend to incriminate an unrecognised arterial injury or obstruction similar to that in supracondylar fractures (Type I injury). Indeed, 
two children (Cases 29 and 37) had documented thrombosis of the femoral artery and underwent thrombectomy and fasciotomy at twenty-four and thirty hours after injury; the delay in recognising the arterial injury and compartment syndrome probably accounted for the poor results. Mustard and Bull (1962) documented femoral artery spasm in dogs after overdistraction of femoral fractures. This mechanism may have played a role in two patients whose fractures were distracted.

Traction apparatus. With skin traction in a Thomas' splint, the uninjured leg is not suspended; thus it is more difficult to incriminate the traction. Involvement of the calf and the erythematous skin changes posteriorly suggest the aetiology: direct pressure secondary to the traction apparatus, calf sling, and rigidly fixed leg. Similar skin findings have been noted in compartment syndromes induced by drug overdose and limb compression (Mubarak and Owen 1975; Owen et al. 1979). Elevation of the leg, as with Bryant's traction, may also play a role. Matsen et al. (1977) have demonstrated that elevation of the leg in an adult decreases blood pressure at the ankle quite significantly in a compromised compartment.

It is probable that the combination of arterial spasm or injury, elevation of the leg and direct pressure leads to involvement of the superficial posterior compartment. Careful and frequent neurovascular examination of children treated with this form of traction is mandatory. Perhaps, as with Bryant's traction, an alternative form of traction should be used.

Tibial injuries. The types of tibial injuries leading to a Volkmann's contracture were quite varied. As with fractures of the forearm, nearly all of these cases were due to compartment syndromes alone without injury to a large vessel. The association of compartment syndromes and Volkmann's contracture with tibial fractures, leg lengthening, and tibial rotational osteotomies has been well documented in the literature (Ellis 1958; Steel, Sandrow and Sullivan 1971; Jackson and Waugh 1974; Matsen and Staheli 1975; Rorabeck and Macnab 1976). The three cases of Volkmann's contracture resulting from a bone-grafting procedure have not been previously reported.

We recommend that prophylactic fasciotomies be performed on all elective tibial operations including leg lengthenings or rotational osteotomies. Internal or external fixation of tibial fractures associated with compartment syndromes allows for easier handling of the fasciotomy wounds.

Miscellaneous. There was only one case of a compartment syndrome secondary to a haemorrhage in a haemophiliac. This occurrence is well documented in the literature (Lancourt, Gilbert and Posner 1977). "Wringer" injuries have declined markedly in the past twenty years. Stone, Cantwell and Fulenwider (1976) reviewed the records of 483 children hospitalised for this injury over a twenty-year period and had no case of Volkmann's contracture. There was only one case of Volkmann's contracture following a wringer accident in this review.

Over the past twenty years the frequency of Volkmann's contracture at the Hospital for Sick Children has not declined in spite of many published reports on compartment syndromes, and on the hazards of supracondylar fractures and of Bryant's traction. Most of the fifty-five children reviewed here did not have early appropriate treatment. Awareness of the common fractures in children that could lead to this complication must be reinforced by the physician, as well as awareness of the early symptoms and signs of impending vascular injury whether due to arterial injury, compartment syndrome or both. Measurement of tissue pressure will aid in the prompt diagnosis and treatment of compartment syndrome, the primary cause of Volkmann's contracture.

\section{REFERENCES}

Brooks, B. (1922) Pathologic changes in muscle as a result of disturbances of circulation, an experimental study of Volkmann's ischemic paralysis. Archives of Surgery, 5, 188-216.

D'Ambrosia, R. D. (1972) Supracondylar fractures of humerus-prevention of cubitus varus. Journal of Bone and Joint Surgery, 54-A, 60-66.

Dodge, H. S. (1972) Displaced supracondylar fractures of the humerus in children-treatment by Dunlop's traction. Journal of Bone and Joint Surgery, 54-A, 1408-1418.

Eichler, G. R., and Lipscomb, P. R. (1967) The changing treatment of Volkmann's ischemic contractures from 1955 to 1965 at the Mayo Clinic Clinical Orthopaedics and Related Research, 50, 215-223.

Ellis, H. (1958) Disabilities after tibial shaft fractures, with special reference to Volkmann's ischaemic contracture. Journal of Bone and Joint Surgery, 40-B, 190-197.

Flynn, J. C., Matthews, J. G., and Benoit, R. L. (1974) Blind pinning of displaced supracondylar fractures of the humerus in children. Journal of Bone and Joint Surgery, 56-A, 263-272.

Gelberman, R. H., Zakaib, G. S., Mubarak, S. J., Hargens, A. R., and Akeson, W. H. (1978) Decompression of forearm compartment syndromes. Clinical Orthopaedics and Related Research, 134, 225-229.

Grimths, D. Ll. (1940) Volkmann's ischaemic contracture. British Journal of Surgery, 28, 239-260.

Holden, C. E. A. (1975) Compartmental syndromes following trauma. Clinical Orthopaedics and Related Research, 113, 95-102.

Jackson, J. P., and Waugh, W. (1974) The technique and complications of upper tibial osteotomy. Journal of Bone and Joint Surgery, 56-B, 236-245.

Jepson, P. N. (1926) Ischaemic contracture. Annals of Surgery, 84, 785-795.

Lancourt, J. E., Gilbert, M. S., and Posner, M. A. (1977) Management of bleeding and associated complications of haemophilia in the hand and forearm. Journal of Bone and Joint Surgery, 59-A, 451-460. 
Lipscomb, P. R. (1956) The etiology and prevention of Volkmann's ischemic contracture. Surgery, Gynecology and Obstetrics, 103, 353-361.

Matsen, F. A., III, Mayo, K. A., Krugmire, R. B., Jun., Sheridan, G. W., and Kraft, G. H. (1977) A model compartmental syndrome in man with particular reference to the quantification of nerve function. Journal of Bone and Joint Surgery, 59-A, 648-653.

Matsen, F. A., III, and Staheli, L. T. (1975) Neurovascular complications following tibial osteotomy in children. Clinical Orthopaedics and Related Research, 110, 210-214.

Miller, D. S., Markin, L., and Grossman, E. (1952) Ischemic fibrosis of the lower extremity in children. American Journal of Surgery, N.S. 84, 317-322.

Mubarak, S. J., and Owen, C. A. (1975) Compartmental syndrome and its relation to the crush syndrome: a spectrum of disease. (linical Orthopaedics and Related Research, 113, 81-89.

Mubarak, S. J., and Owen, C. A. (1977) Double-incision fasciotomy of the leg for decompression in compartment syndromes. Journal of Bone and Joint Surgery, 59-A, 184-187.

Mubarak, S. J., Owen, C. A., Hargens, A. R., Garetto, L. P., and Akeson, W. H. (1978) Acute compartment syndromes: diagnosis and treatment with the aid of the Wick catheter. Journal of Bone and Joint Surgery, 60-A, 1091-1095.

Murphy, J. B. (1914) Myositis. Journal of the American Medical Association, 63, 1249-1255.

Mustard, W. T., and Bull, C. (1962) A reliable method for relief of traumatic vascular spasm. Annals of Surgery, 155, 339-344.

Nicholson, J. T., Foster, R. M., and Heath, R. D. (1955) Bryant's traction-a provocative cause of circulatory complications. Journal of the American Medical Association, 157, 415-418.

Owen, C. A., Mubarak, S. J., Hargens, A. R., Rutherford, L., Garetto, L. P., and Akeson, W. H. (1979) Intramuscular pressures with limb compression: clarification of the pathogenesis of the drug-induced compartment syndrome/crush syndrome. New England Journal of Medicine, (in press).

Rorabeck, C. H., and Macnab, I. (1976) Anterior tibial-compartment syndrome complicating fractures of the shaft of the tibia. Journal of Bone and Joint Surgery, 58-A, 549-550.

Steel, H. H., Sandrow, R. E., and Sullivan, P. D. (1971) Complications of tibial osteotomy in children for genu varum or valgum. Journal of Bone and Joint Surgery, 53-A, 1629-1635.

Stone, H. H., Cantwell, D. V., and Fulenwider, J. T. (1976) Wringer arm injuries. Journal of Pediatric Surgery, 11, 375-379.

Thomas, J. J. (1909) Nerve involvement in the ischaemic paralysis and contracture of Volkmann. Annals of Surgery, 49, 330-370.

Thomson, S. A., and Mahoney, L. J. (1951) Volkmann's ischaemic contracture and its relationship to fracture of the femur. Journal of Bone and Joint Surgery, 33-B, 336-347.

Whitesides, T. E., Jun., Harada, H., and Morimoto, K. (1977) Compartment syndromes and the role of fasciotomy. its parameters and techniques. American Academy of Orthopaedic Surgeons, Instructional Course Lectures, 26, 179-196.

Winslow, P. M. (1950) Circulatory complications from Bryant's traction, read before Interurban Orthopaedic Club Program. Rochester, N.Y. Oct. 19.

Volkmann, R. (1881) Die ischaemischen Muskellähmungen und -Kontrakturen. Centralblatt für (hirurgie, 8, 801-803. 